\title{
Study of selection and purification of Brazilian bentonite clay by elutriation: a XRF, SEM and Rietveld analysis
}

\section{(Estudo da seleção e purificação de argila bentonita brasileira por elutriação: análise por FRX, MEV e Rietveld)}

\author{
J. L. Alves", A. E. Zanini, M. E. de Souza, M. L. F. Nascimento ${ }^{* *}$ \\ Graduating Program in Industrial Engineering, Department of Chemical Engineering, Polytechnic School, \\ Federal University of Bahia - PROTEC / PEI \\ *jeff_eq@yahoo.com.br,**mlfn@ufba.br
}

\begin{abstract}
Clays obtained from nature have a lot of impurities. Therefore, for best using of these materials, it is necessary its selection and purification. Thus, the aim of this work is to separate and to purify the smectite fractions using water as a solvent at a low flux mixed with a bentonite clay extracted from a mine in Vitória da Conquista - Bahia / Brazil. For this a separation method of fractions of expandable clays based on the Stokes' Law was applied - this process is called elutriation, in order to ensure and to expand possible industrial applications of this material. The samples were characterized by analysis of X-ray diffraction, X-ray fluorescence and scanning electron microscopy. The Rietveld method enabled the quantification of main phase minerals: montmorillonite, kaolinite, nontronite and quartz, reaching $85 \%$ in mass of montmorillonite phase at the end of the process. Results showed that the method used was efficient to remove almost all quartz, carbonates and organic matter from the sample. It was also observed a monomodal grain size distribution of elutriated materials with thinner grains, around $(18.1 \pm 1.8) \mu \mathrm{m}$ at the end of the process. It has been concluded that the method developed and applied showed promising characters to be applied to elutriate kilograms of clays and could be used in industrial scale.
\end{abstract}

Keywords: bentonite clays, purification, elutriation, XRD-Rietveld.

Resumo

\begin{abstract}
Argilas obtidas da natureza contêm muitas impurezas. Portanto, para melhor utilização destes materiais, é necessária a sua selecção e purificação. Assim, o objetivo deste trabalho é de separar e purificar frações esmectíticas utilizando água como solvente em baixo fluxo misturada com uma argila bentonítica extraída de uma mina em Vitória da Conquista - Bahia / Brasil. Para tanto foi aplicado um método de separação de frações de argilas expansíveis baseado na Lei de Stokes - processo este denominado elutriação, de forma a garantir e expandir possiveis aplicações industriais deste material. As amostras foram caracterizadas por análise de difração de raios $X$, fluorescência de raios X e microscopia eletrônica de varredura. $O$ método de Rietveld permitiu a quantificação das principais fases minerais: montmorilonita, caulinita, nontronita e quartzo, alcançando $85 \%$ em massa da fase montmorilonita a fim do processo. Os resultados mostraram que o método utilizado foi eficiente para remover quase todo o quartzo, carbonatos e matéria orgânica a partir da amostra. Observou-se também uma distribuição monomodal de tamanhos de grão dos materiais elutriados com grãos finos, por volta de $(18,1 \pm 1,8)$ um ao fim do processo. Concluiu-se que o método desenvolvido e aplicado mostrou resultados promissores a serem aplicados de modo a elutriar quilogramas de argilas e pode ser utilizado em escala industrial.
\end{abstract}

Palavras-chave: argilas bentonitas, purificação, elutriação, DRX-Rietveld.

\section{INTRODUCTION}

Clays, modified or in natura, have been recognized as the construction materials of the century due to its abundance, low cost and its environmental friendship [1]. Clays applications has been initiated by primary men, when it was used to manufacture "modelling clay" as bricks, statuettes, vases, pots, among others [2]. Probably even before the human existence, according to a theory proposed by Cairns-Smith, it was possible the existence of a simple intermediate step between the lifeless matter and the organic substance, consisting of crystals replication of clay materials in suspension from the known mechanisms of crystallization [3]. The clay definition according to Santos [2] is of a natural material, earthy, with thin granulation $(2 \mu \mathrm{m})$ that when wet presents plasticity, and it is essentially constituted by a group of minerals generally named clays, that are associated to impurities as organic matter, soluble salts, quartz, feldspar, mica, pyrite, calcite, chlorite, sulfates, sulfites, carbonates and others residual coumpounds. Chemically, these materials are formed essentially by hydrated aluminum silicates, iron and magnesium. Any clay can be composed 
by a single clay mineral or by a mixture of them. Bentonites, specifically, are composed by clay minerals of the smectite group, predominantly by montmorillonite (M) phase [2]. Currently bentonite has consolidated its relevance in various industrial activities. The demand and the emergence of new applications for this specific phase is continuously increasing, for example, by means of fertilizers, catalysts, adsorbents, desiccants, refractory bricks, bleaching agents, paints, filter agents, dyes and others [4]. This wide range of applications is due to inherent facilities as large selection, easy extraction, low cost and particular properties as swelling, adsorption, rheological and colloidal behavior, plasticity, among others $[2,5,6]$.

Currently in Brazil, the state of Paraíba is the main bentonite producer. However the deposits in this locality have been exhausted due to several years of extraction, making thus necessary to search for new production sources. A newly discovered mine in Bahia State, at Vitória da Conquista city, operated by Companhia Brasileira de Bentonita, produces closed to $100,000 \mathrm{t} /$ year of bentonite during these recent years [7]. This ore in raw form has impurities that can compromise the quality of some of its applications. Brazilian bentonite clay is essentially polycationic and predominantly contains calcium and magnesium, and may contain different amounts of clay minerals, including mixed layers of illitemontmorillonite [8]. The national reserves are $31.4 \times 10^{3}$ tons, and the Brazilian state of Paraná concentrates $48.2 \%$ of the total, the state of Paraíba covers $24.5 \%$, S. Paulo contains $17.9 \%$ and Bahia has $9.4 \%$. Paraíba is the main bentonite producer in Brazil, highlighting the city of Boa Vista [9]. The bentonite clay is typically extracted from open-air mines with deposits of varying depths, from few centimeters to several meters and many impurity types. Clay purification is a complex and expensive process, which consists in the bentonite specific case, to proceed selection and separation of montmorillonite from other impurities, which inhibit their properties of high interest, thus compromising its applications. Depending on the application for which the clay is intended, it usually requires, in addition to purification, cationic modifications, because the clay minerals are usually found in its calcium form, and calcium montmorillonite (CaM) has low expansion, which hinders the cation exchange capacity that is the essential property for many applications of this phyllosilicate. Therefore, it is usually necessary to sodified this material (Na-M). A specific application refers to montmorillonite use in nanocomposites, which requires that clay presents a organophilic or hydrophobic nature (in opposition to its natural state, hydrophilic) - it is thus important to create specific interactions and bondings with a polymer matrix (which has a organophilic character) for the formation of new nanomaterials [10]. For this particular organoclay production to obtain polymer nanocomposites, very pure clays are extremely necessary, because the amount of impurities may not exceed 5\%, mainly due to changes in the cation exchange capacity. Impurities also affect the properties and the quality of polymer nanocomposites for industrial applications, such as its use as films and bottles for food and beverage industries, where impurities drastically affect the barrier properties of the material $[8,10]$.

It is proposed in this work to investigate the feasibility of a technique to select and purify up to kilograms of bentonitic clay based on Stokes' Law [11], in particular on a extracted bentonite from a Brazilian mine. This law allows to calculate settling velocity of a spherical particle in a viscous fluid, where the main parameters involved are the differences of viscosity between the particle and fluid densities, the diameters of particle and the viscosity that opposes to the field. From this premise has been proposed, developed and applied a method of separation of fractions of expandable clays called "elutriation". For this work, bidiametric columns were used in which was apllied a water flow opposite to the gravitational downward movement of the particles, properly controlled in order to obtain adequate fluid velocities, in order to obtain a monomodal grain size distribution [8]. Thus, four columns in series were employed to maximize the process. Results obtained may enable to plan a construction of a pilot plant and new applications for these clays for industrial processes, according to a Brazilian patent [12]. To quantify the main phases, the Rietveld Method was applied, due to the well-know difficulty to carry out a quantitative analysis of multi-component systems as clays, mainly due to the overlaping peaks from XRD diffraction $[13,14]$. This method consists as a least-square wholepattern-fitting structure refinement, perfomed until the best fit is obtained between the powder diffraction pattern and a calculated one, that takes into account the composition and crystal structure of each mineral phase, suggested by previous qualitative analysis. Such characterization technique can be combined with SEM, XRF and grain size distribution, which offer a unified view of a specific clay selection and purification by means of the elutriation process.

\section{Elutriation: brief theory}

The elutriation technique could be applied to any inorganic matter, specially Brazilian clays [8]. As far authors know, Schulze was the first to construct and use an ellutriator to purify and separate minerals [15]. Since the 1920 s, this method has been used to manage experimental process selection and purification of clays [16, 17]. This technique uses the Stokes' Law [11], which can determine the decantation terminal velocity of a particule in a viscous flow. The principle of the law determines that a sphere of radius $r$ immersed in a fluid is submited to two forces: the resistence $R$, due to the fluid viscosity $\eta$ :

$$
\mathrm{R}=6 \pi \mathrm{r} \eta \mathrm{v}_{\mathrm{f}}
$$

and the gravity:

$$
\mathrm{F}=\frac{4}{3} \pi \mathrm{r}^{3} \delta_{\mathrm{p}} \mathrm{g}
$$

where $\delta_{p}$ is the density of the particle, which reaction is moderate by the upward buoyant force " $P$ " according to 
Archimede's Principle:

$$
\mathrm{I}=\frac{4}{3} \pi \mathrm{r}^{3} \delta \mathrm{g}
$$

where $\delta$ is the density of the fluid [18]. Assuming that the initial velocity of the sphere is equal zero, its movement occurs only when the force resulting from $F-I$ difference is superior than the resistance $R$. The particle is then subject to the accelerating movement, until its velocity induces in the fluid a resistance exactly equal to the resulting force. The sphere will then enter in a constante velocity of fall (named terminal velocity, $v_{f}$ ) [18]. In the conditions mentionned above, the equation that determines the movement can be expressed as:

$$
v_{\mathrm{f}}=\mathrm{kg} \frac{\left(\delta_{\mathrm{r}}-\delta\right)}{\eta} \mathrm{r}^{2}
$$

where $g$ corresponds to the acceleration of gravity and $k$ a constant with a value near $2 / 9$ for spheric particles isolated and without specific interaction [18]. In this work, Equation (D) could be applied under some considerations and aproximations. The clay particles can be considered more or less arbitrarly spheroidal, since the radius could be interpretated as an equivalent radius to the particle. Zanini studied these efects and considerations in bentonites, leading to a modified Stokes equation equals to:

$$
v_{\mathrm{f}}=\mathrm{g} \frac{\left(\delta_{\mathrm{p}}-\delta\right)}{2.1 \eta} \mathrm{d}^{2}
$$

where $d$ corresponds to the equivalent diameter of the particle and $\delta_{p}$ is around $2.6 \mathrm{~g} / \mathrm{cm}^{3}$ [8]. In short, elutriation is basically a separation process that, depending on the flow which is established in the elutriation column, yields a separation of particles of a given diameter. As the flow increases, particles with larger diameters are separated. This equation describes which velocity is necessary to establish a laminar flow of a fluid to drag determined spherical particle, given its diameter and density. The terminal velocity $v_{f}$ is directly proportional to the difference between the densities of the particle and fluid $\left(\delta_{p}-\delta\right)$ and the square of the particle diameter $\left(d^{2}\right)$. The viscosity $\eta$, in turn, acts with inversely proportional form to $v_{f}$ and it was applied by Zanini for some clays [8].

In a well-dispersed suspension of clay in water, after reaching equilibrium hydration, different settling velocities can be observed. Visually the change in turbidity over time can be observed and is easy to note that the speed of sedimentation of fine particles is smaller than that of larger particles. Stokes' Law, established in Equation (E) quantifies this observation. Thus, if a cross-flow (counterflow) without turbulence is applied with a constant speed and according to Stokes' Law, three situations are possible, setting the elutriation process (where $U_{f}$ is the fluid velocity): a) particles will settle $\left(v_{f}>U_{f}\right)$; b) particles will have zero velocity sedimentation $\left(v_{f}=U_{f}\right)$; c) particles will be transported $\left(v_{f}<U_{f}\right)$ [8]. It is noteworthy that the expansion capacity of montmorillonite is due to the intercalation of polar molecules, or molecules that may cause cationic substitution between their lamellae. This phenomenon causes a change in the density of the clay in function of this volumetric modification. Therefore it can be said that these clay minerals are able to swell in contact with water, reducing its density, and the mineral contaminants do not have this ability; moreover the average particle size of the disaggregated $\mathrm{M}$ phase is also much lower than that of natural contaminants of mineral origin, therefore these factors will provide the separation of the clay mineral of interest [8].

\section{EXPERIMENTAL}

In this work we will denote Clay VC: in natura as the polycationic bentonite supplied by Companhia Brasileira de Bentonite, extracted from a mine located in Vitoria da Conquista, Bahia, Brazil. The clay was treated with acetic acid with $99.8 \%$ purity, supplied by $\mathrm{F}$. Maia Indústria e Comércio Ltda.

\section{Chemical treatment}

Acetic acid was applied to the samples as a previous chemical treatment, in order to assist some removal of impurities during elutriation. The technique aims to decompose some impurities on carbonate forms, which are insoluble in water, and which aggregate to outside clay surface particles, affecting some properties. Then, the acid was added in order to react with these salts, inter alia, $\mathrm{Na}_{2} \mathrm{CO}_{3}, \mathrm{MgCO}_{3}, \mathrm{CaCO}_{3}$, resulting in carbon dioxide, water and metallic salts, which are soluble components in water and can therefore be eliminated during the elutrition by the flow of water that was used in the process. However, this technique must to be handled, taking precautions with the $\mathrm{pH}$ of dispersion, so that a carefull procedure should be done to not modify the clay structure by acid. In this way the dispersion $\mathrm{pH}$ was controlled to stay between 3.5 and 4 [1]. Acetic acid was choosen to apply following this procedure because it is a weak acid. Thus, the dispersion $\mathrm{pH}$ was monitored following the method described by Keller, using $\mathrm{pH}$ indicator strips [19].

\section{Experimental procedure for material preparation}

First, the in natura material was subjected to a mechanical treatment in order to disaggregate the particles and thus improve its separation during elutriation. Then it was subjected to chemical treatment with acetic acid, in order to assist in removing carbonates (insoluble in water). The mechanical procedure was by attrition, as follows: in a $100 \mathrm{~mL}$ beaker were weighed $100 \mathrm{~g}$ of in nature clay. In a graduated cylinder, $700 \mathrm{~mL}$ of distilled water was measured, and $200 \mathrm{~mL}$ were added in a industrial Metvisa blender made of inox steel with a maximum speed of $1200 \mathrm{rpm}$. 
After adding water with clay to the blender, the dispersion was stirred for $1 \mathrm{~min}$. While the solution remained at rest for $1 \mathrm{~min}$, the internal part and lid of the blender were cleaned with the aid of a squeeze, and this process was repeated five times. Then a solution of $1 \mathrm{M}$ acetic acid was slowly added to the suspension under stirring until reach a $\mathrm{pH}$ around 4. After the chemical treatment the suspension was placed in a ultrasound Ultra Cleaner 1400 - Unique, with a standard frequency of $60 \mathrm{~Hz}$, applied at room temperature for $2 \mathrm{~h}$. After this, the dispersion was once again stirred and then placed in the elutriator.

The elutriation system consisted of four columns of borosilicate glass in series, the first and the second with an average diameter of $5.57 \mathrm{~cm}$ and $140.5 \mathrm{~cm}$ height, the third with an average diameter of $11.40 \mathrm{~cm}$ and $145.2 \mathrm{~cm}$ height, and the fourth with an average diameter of $21.18 \mathrm{~cm}$ and $145.6 \mathrm{~cm}$ height. The elutriation procedure was quite simple. The dispersion was transferred with the aid of a funnel to a bottle dosage for the columns. All elutriation system were connected in series and the water flow was adjusted with the aid of a needle valve properly calibrated, obtaining a flow rate of approximately $(28.2 \pm 1.3) \mathrm{g} / \mathrm{min}$. The elutriation was monitored until the system reached equilibrium, i.e., all particles were transferred until a steady state in the four columns, thus indicating the end of the process. After separation, the fractions collected from each column were placed in dishes to dry with the aid of a fan at room temperature for three days. After drying, samples were ground in a mortar and agata pestle, and sieved in an ABNT sieve of number 100 mesh $(150 \mu \mathrm{m}$ aperture) for characterization analysis. It was possible to elutriate more than $200 \mathrm{mg}$ in this work, reaching up to $700 \mathrm{mg}$ for the whole system. Some simple calculations showed that an industrial scale can produce kilograms of elutriated material [12].

\section{Characterization methods}

$\mathrm{X}$-ray diffraction measurements were conducted in a X-ray diffractometer Shimadzu XRD-6000, with $\mathrm{Cu}-\mathrm{K}_{\alpha}$ radiation $(\lambda=1.542 \AA), 30 \mathrm{kV}$ voltage, $15 \mathrm{~mA}$ electric current, scanning from 2 to $50^{\circ}$ in $2 \theta$ and scan speed of $0.25^{\circ}$ per step, with a counting time of $1 \mathrm{~s}$ per step. The data were collected using a $0.5 \mathrm{~mm}$ divergence slit along with a 0.5 and 0.3 $\mathrm{mm}$ receiving slits. Powder samples were placed on an aluminum sample holder, pressed to obtain a regular surface and inserted in the diffractometer goniometer support. A silicon standard was used to calibrate the equipment. The qualitative interpretation was performed by comparison with existing standards on PDF2 database (the International Centre for Diffraction Data, ICDD: www.icdd.com, 1996) using specific software. Quantitative analysis was performed by means of Rietveld refinement method [13, 14] by means of the DBWS Tools 2.4 for Windows [20].

The chemical composition of the samples were determined using a sequential spectrometer of X-ray fluorescence per wavelength XRF - 1800 Shimadzu; the powdered samples were pressed to disc shape under a pressure of 10 ton, using boric acid as support (base). The morphology of the samples were observed with a scanning electron microscope (SEM) SSX-550 Shimadzu, with $10 \mathrm{kV}$ voltage under vacuum; preparation was performed applying a little amount of powder on a carbon tape and all samples were metalized with gold.

\section{RESULTS}

\section{Chemical analysis by X-ray fluorescence}

Table I shows the XRF results from in natura sample (VC-IN), and the samples obtained from first (VC-EL-COL ${ }_{1}$ ) and forth (VC-EL-COL ${ }_{4}$ ) columns. The table presents the variation of chemical composition of these samples and the modifications during the process of purification. The results illustrate a graduated increment of silicon and aluminium elements between the sample without purification, and the elutriation results from the first and the fourth columns. Silica $\left(\mathrm{SiO}_{2}\right)$ is related to quartz mineral impurities, and it is also one of the constituents of clay mineral montmorillonite. $\mathrm{Al}_{2} \mathrm{O}_{3}$ is mainly associated with montmorillonite and kaolinite, because impurities like quartz do not have aluminium in its composition. Thus, doing a relative analysis of variation of these elements, we could notify that the increase of the concentration thereof between the column 1 and the column 4 is directly correlated with increased content of montmorillonite due to the elutriation process; in other words, the result shows that the fraction of column 1 presents quartz content greater than the fraction of column 4 , showing that this impurity was retained in the first column, and the column four has a higher content of clay minerals

Table I - Results of chemical analysis from X-ray fluorescence (in $\mathrm{wt} \%$ ).

[Tabela I - Resultados da análise química de fluorescência de raios $X$ (em \% em massa).]

\begin{tabular}{cccc}
\hline Component & VC-IN & VC-EL-COL & VC-EL-COL \\
\hline $\mathrm{SiO}_{2}$ & 55.5559 & 60.9223 & 62.8574 \\
$\mathrm{Al}_{2} \mathrm{O}_{3}$ & 22.0061 & 22.0078 & 22.618 \\
$\mathrm{Fe}_{2} \mathrm{O}_{3}$ & 6.7387 & 9.4662 & 8.2045 \\
$\mathrm{MgO}$ & 3.1727 & 3.3696 & 3.4978 \\
$\mathrm{CaO}$ & 0.1505 & 1.7214 & 2.0238 \\
$\mathrm{Na}_{2} \mathrm{O}$ & 0.0578 & 0.0726 & 0.1212 \\
$\mathrm{~K}_{2} \mathrm{O}$ & 0.0202 & - & 0.0495 \\
$\mathrm{TiO}_{2}$ & 0.3741 & 1.1433 & 0.2057 \\
$\mathrm{CuO}$ & 0.0163 & 0.1818 & 0.1069 \\
$\mathrm{CO}_{2}$ & 11.6495 & - & - \\
$\mathrm{SO}_{3}$ & - & 0.0429 & 0.0558 \\
$\mathrm{Cr}_{2} \mathrm{O}_{3}$ & 0.1003 & 0.1407 & 0.1272 \\
$\mathrm{ZnO}$ & - & 0.0378 & 0.0616 \\
$\mathrm{Others}$ & 0.1279 & 0.8936 & 0.0706 \\
\hline
\end{tabular}


of that found on the first column, and these analysis are in agreement with the next XRD results.

Still analyzing Table I, it is noticed that there was an increase in the concentration of some elements between the sample VC-IN and the elutriated samples, as iron, calcium, sodium, copper, sulfur and zinc, which may have been caused by water used in the purification process, which was a water of public distribution system without treatment. Another very positive result, according with Table I, was the total elimination of the carbon between the in natura clay (containing about $10 \%$ carbon) and the fractions after elutriation. The elimination of organic and some inorganic impurities (mainly insoluble carbonates in water), which is constituted by this element, in addition to quartz, consisted of the main focus of this work, since these impurities cooperate as a major interference in the properties and applications of clay in question. Based on the results presented to $\mathrm{CO}_{2}$, it is evident that the purification method used, both the elutriation as chemical treatment with acetic acid, were successful in separating and removing these impurities.

\section{Analysis by $X$-ray diffraction (XRD)}

The X-ray diffraction of in natura and purified samples colected in the first and last columns by means of elutriation are shown in Fig. 1. In general, we can see that all samples showed montmorillonite as the major phase, represented by the first peak of higher intensity. As discussed in the chemical analysis section, the elutriation proved efficient in the selection and purification of montmorillonite phase,

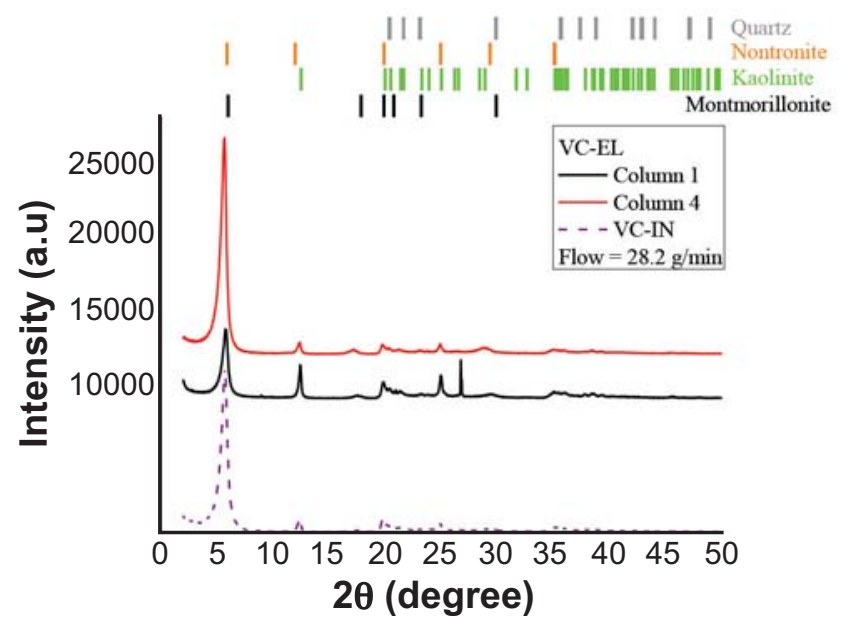

Figure 1: X-ray diffractogram of the elutriated and in natura fractions of VC clay, indicated column by column. Each intensity is in counts per second. It was used a flux of $28.2 \mathrm{~g} / \mathrm{min}$ for the elutriation process. The main phases observed were: montmorillonite, kaolinite, nontronite and quartz.

[Figura 1: Difratograma de raios $X$ das frações elutriadas $e$ in natura de argila VC, indicados coluna por coluna. Cada intensidade refere-se a contagens por segundo. Foi utilizado um fluxo de 28,2 g/min no processo de elutriação. As principais fases observadas foram: montmorilonita, caulinita, nontronita $e$ quartzo.] showing considerable increase in the relative intensity peak to peak, as well as the narrowing of the highest peak, with $d_{001}$ around $15 \AA$, comparing the data between the first and last columns. The proposed method also was efficient in removing impurities, mainly quartz, represented by the main peaks at approximately $20.8^{\circ}$ and $26.6^{\circ}$ in the sample of column one, where it was more retained, beyond of the reduction of kaolinite $\left(2 \theta=12.2^{\circ}\right.$ and $\left.24.8^{\circ}\right)$ as well as nontronite phases between the columns one and four. The lower quartz content in the natural sample simple means that they were distributed in all four columns during elutriation (but not shown in figure). In fact, higher quartz amount was observed in column 1. This is also in agreement with results shown in Table I, because there are more silicon tetahedra structures in clay phases but XRF technique only see $\mathrm{SiO}_{2}$, that is increasing from column 1 to 4 . Iron and calcium, as well as other substances incorporated in clay analysis can be originated from water used in the elutriation process - just filtred.

The mineralogical characterization through mineral quantification of Brazilian clays by XRD data using Rietveld method is not common. A quantitative analysis is shown in Table II. The strategy adopted was: i) all scale factors were adjusted at the same time; ii) for each phase, the scale factor, overall temperature factor, lattice parameters, $\mathrm{U}, \mathrm{V}$ and $\mathrm{W}$ parameters of the FWHM, NA and NB parameters were adjusted separately one by one and then simultaneously; iii) the six terms of the polynomial function used to model the background were refined one by one and finally joined; iv) all the scale factors cited, this background, the sample displacement and the zero- $2 \theta$ were adjusted simultaneously. The refinement progress of each sample was evaluated by numerical criteria, as defined by the program DBWS 9807a, namely the R-expected $\left(R_{\text {exp }}\right)$ and goodness of fit $(S)$. The crystalline structure data of each phase were downloaded from ICSD - Inorganic Crystal Structure Database as well as from literature. The best-matching crystallographic information files were used for the refinement. For details see: montmorillonite [21]; kaolinite [22]; nontronite [23]; quartz [24]. From results, there is a visible increase at $d_{001}$ intensity from montmorillonite (M) phase, just comparing columns 1 and 4. It is also evident that $d_{001}$ intensity is higher than in natura, showing a selection process. Such results, obtained in a pilot plant scale, can be visualized to occur in an industrial scale, promoting a separation and purification process of clay kilograms, following a recent patent [12]. Kaolinite $(\mathrm{K})$, nontronite $(\mathrm{N})$ and quartz $(\mathrm{Q})$ phases diminish from columns 1 to 4 , but the selection process occurs in different ways column by column for each of these phases. Just to simplify our argument, only the first and last columns were analyzed. We noted that at the last elutriation column there was an increasing of $\mathrm{M}$ phase, showing that we also observed a purification process, even considering in natura sample.

Rietveld method results for the clay fractions (Fig. 1 and Table II) showed that sodium and calcium results agree with the XRF (Table I). The presence of Ti and Fe determined 
Table II - Mineral composition mass percentage of main phases observed column by column (as well as the in natura sample) by means of Rietveld method $[13,14]$ using the DBWS Tools 2.4 for Windows [20]. $R_{\text {exp }}$ and $S$ are refinement parameters.

[Tabela II - Composição mineral em percentagem em massa das principais fases observadas coluna por coluna (bem como da amostra in natura) por meio do método de Rietveld [13, 14], utilizando o DBWS Tools 2.4 para Windows [20]. $R_{\text {exp }}$ e $S$ são parâmetros de refinamento.]

\begin{tabular}{ccccccc}
\hline Column & Montmorillonite $(\mathrm{M})$ & Kaolinite $(\mathrm{K})$ & Nontronite $(\mathrm{N})$ & Quartz $(\mathrm{Q})$ & $R_{\exp }(\%)$ & $S$ \\
\hline in natura & $78.30 \pm 0.93$ & $19.01 \pm 4.69$ & $2.01 \pm 2.22$ & $4.74 \pm 1.50$ & 5.48 & 25.07 \\
1 & $29.86 \pm 1.47$ & $40.43 \pm 2.93$ & $13.08 \pm 2.88$ & $16.62 \pm 2.34$ & 5.64 & 4.33 \\
4 & $84.92 \pm 1.59$ & $5.62 \pm 0.43$ & $1.86 \pm 1.08$ & $7.60 \pm 1.29$ & 5.17 & 10.32 \\
\hline
\end{tabular}

by XRF could indicate rutile/anatase as well as hematite presences, but the amounts are too low to be calculated precisely by Rietveld refinement. Rietveld method was carried out taking into consideration the ideal stoichiometry and crystalline structure of a calcic-montmorillonite [21], and the Brazilian clay is probably polycationic, which means that the adjustment would be better with a more reasonable crystalline structure (but not yet determined). Under considering this, it is thus possible to find an agreement with the low number of theoretical crystal structures and the obtained adjustment indices, that varied from 4.33 to 25.07 to $S$ and 5.17 to 5.64 for $R_{\text {exp }}$, according to results shown at Table II. These are quite reasonable, considering the limitations of this method, and particularly for clays. It is also important to cite the influence of the acetic acid, not applied to the in natura sample. Probably such high $S$ value could be related to a more impure sample, and not elutriated, still in agreement with results shown in Table I. More specifically the montmorillonite structure is not well established and this particular phase would have a high cation-exchange capacity. Thus, some adjustments would be better if it would be possible to take into account the precise amount of different ions as sodium and lithium (i.e., substitution for the probable calcic form in montmorillonite phase), dislocations as well as the hydration state in such clay samples analysed. In this way, as a comparative study, the hydration state could be considered the same due to the elutriation process that all clay samples were submitted.

\section{Scanning electron microscopy}

The technique of scanning electron microscopy (SEM) allows to evaluate the morphology of the clay particles, i.e., the geometry (shape), size, and size distribution [25]. The SEM analysis performed on fractions of column one and four are shown in Fig. 2. The morphologies of the montmorillonite phase are similar as the one obtained recently by other authors [25], and in agreement with were obtained from Rietveld method (Table II). XRF technique could not distinguish silicon tetrahedra from montmorillonite, kaolinite and quartz structures. Fig. 2 refers to low-magnification micrographs of the samples of the columns 1 and 4. Through them, we can evaluate the size and distribution of particles, and even verify contaminations. Considering the column one sample, one can observe distributions with particle sizes with high range, especially particles with large sizes that can be aggregates
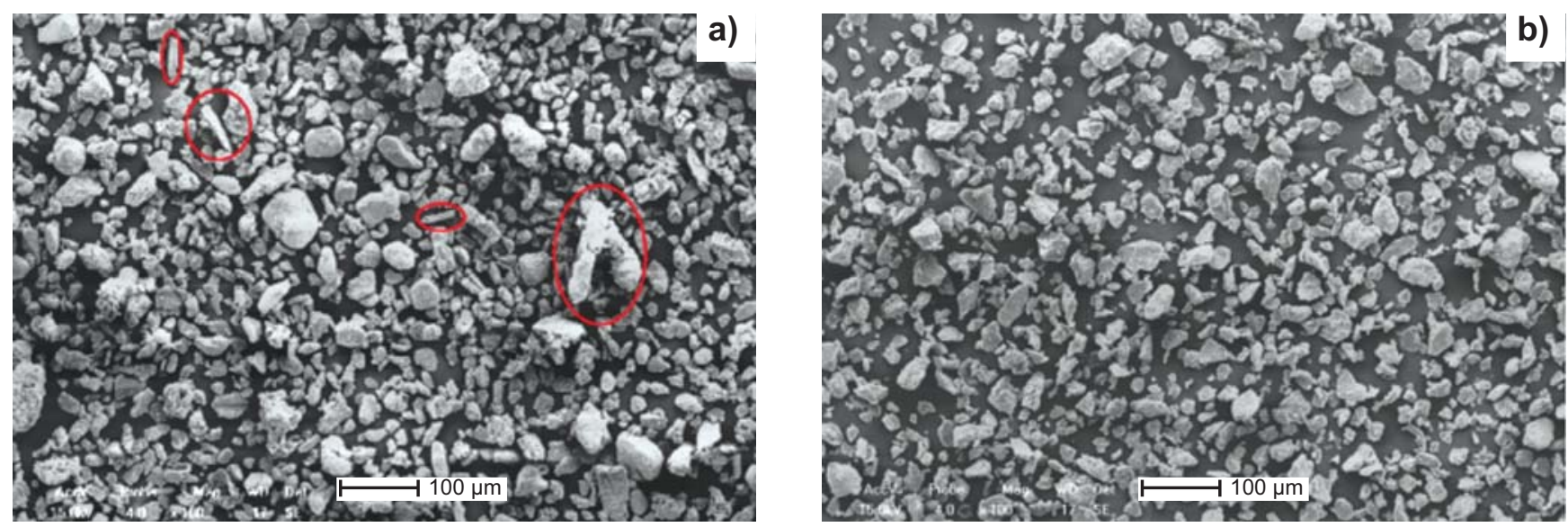

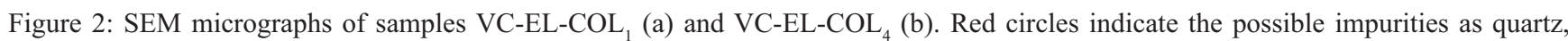
present in the sample.

[Figura 2: Micrografias de MEV de amostras VC-EL-COL $\left(\right.$ a) e VC-EL-COL $L_{4}$ (b). Os círculos vermelhos indicam possíveis impurezas como quartzo, presente na amostra.] 
or impurities, this was expected because it is the densest phase and with larger diameters obtained by elutriation, which is also consistent with the predicted by Stokes' law. In addition there is a very irregular distribution of grain size. The micrograph of this sample revealed particles with various shapes, including non-spheroidal that can be impurities that may be associated with $\mathrm{M}$ phase. Some of these grains with atypical geometry are highlighted. On the other hand the fraction of the material obtained in the fourth column showed a more symmetrical particle size distribution, with smaller average grain sizes, and more concise particle geometry with $\mathrm{M}$ phase expected, which is consistent with the assumptions made for the separation
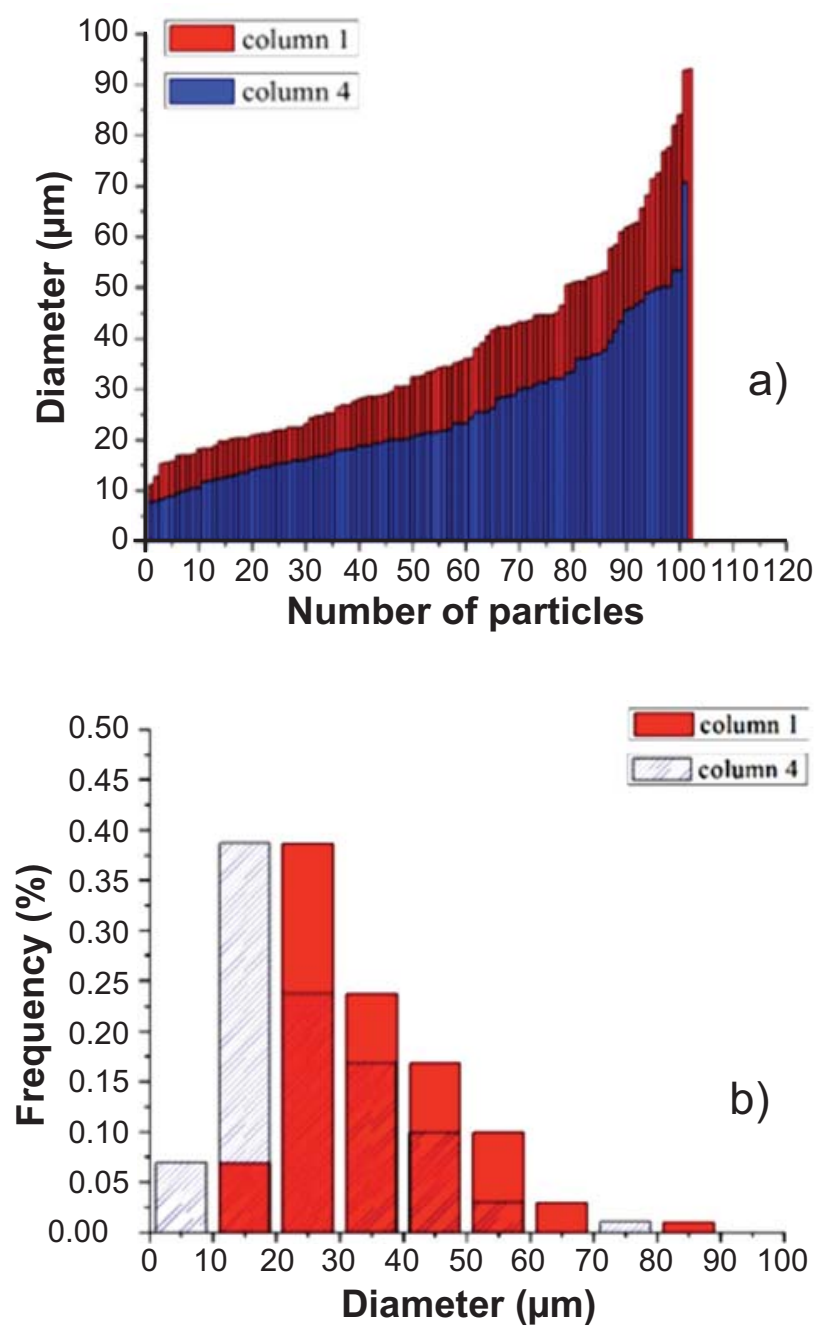

Figure 3: Analysis from SEM images of VC-EL-COL 1 and $\mathrm{COL}_{4}$ : (a) particle size distribution; (b) monomodal histogram of relative frequency distributions of the respective diameters. Column 4 has tiny grains (around $10 \mu \mathrm{m}$ in average) than that observed in column 1 , thus showing a selection process.

[Figura 3: Análise a partir das imagens de MEV de VC-EL-COL e $\mathrm{COL}_{4}$ : (a) distribuição de tamanho de partículas; (b) histograma de distribuição monomodal de frequências relativas dos respectivos diâmetros. A coluna 4 tem pequenos grãos (cerca de $10 \mu \mathrm{m} \mathrm{em}$ média) do que os observados na coluna 1, mostrando então um processo de seleção.] method used and the results obtained by analysis of the previous characterizations. So it is worth noting that the elutriation is an efficient and promising method for the selection, separation and purification of clay materials, as it succeeded in its goal.

\section{Analysis of particle size distribution}

Analysis of particle size distribution was made from the micrographs in Fig. 2. The procedures involved in the treatment and processing of the images were performed in the open software Image J version 1:45. It has been found that the process of elutriation decreased the particle average diameter between the first and fourth columns. For each analysis around a hundred of particles were measured, resulting in a very reasonable statistics. The results showed an unimodal behavior of distribution in which the average diameter calculated for the first column was around of $28.1 \pm 1.8 \mu \mathrm{m}$ and for the fourth column was about $18.1 \pm 1.8 \mu \mathrm{m}$ (Fig. 3).

\section{CONCLUSIONS}

This work aimed to study the effect of a promising method of selection and purification, called elutriation in series, in conjunction with acid treatment, according to the results and analyzes presented. This process promoted an efficiently separation and purification of a bentonite clay from Bahia by selective removal of the montmorillonite fraction considering a low flux, of $28.2 \mathrm{~g} / \mathrm{min}$. This selection can increase the efficiency of operation of this clay, especially in relation to its performance as nanosystem and catalyst. The Rietveld method was efficient in investigating mineralogical properties of such Brazilian clay, preseting reasonable indexes of quality refinement. It was verified and quantified by means of Rietveld refinement method the main phases involved: montmorilonite, kaolinite, nontronite and quartz, with a predominance of the first two minerals. It was also perfomed a comparison of in natura material with elutriated ones, reaching $85 \%$ in mass of montmorillonite phase in the last column. The Rietveld method presented reasonable quality of refinement indexes. An adverse result was the incorporation of certain elements such as iron, calcium and others, probably due to the filtred water used in the elutriation. Another positive result was the total elimination of impurities that containing carbon both organic and inorganic impurities (such as carbonates) using acetic acid. XRF and Rietveld refinements showed indications of such specific influence on results. Particle size analysis confirmed the separation of the sample by monomodal particle size, as was stated by Stokes' law, observing results from column 1 to 4 . Particle sizes from last column were around $(18.1 \pm 1.8) \mu \mathrm{m}$. Finally, it was conclude that this study was successful in its objectives, and that the proposed technique of selection, separation and purification of clays achieved efficiently its purpose, indicating the possibility of building a pilot plant for the production of kilograms of high quality bentonite. 


\section{ACKNOWLEDGMENTS}

The authors acknowledge the CNPQ, CAPES and FAPESB for the financial support. Special thanks to Companhia Brasileira de Bentonita (www.CBB.ind.br) and the Prof. Dr. Laura Hecker de Carvalho, from the Federal University of Campina Grande for valuable discussions.

\section{REFERENCES}

[1] F. Bergaya, B.K.G. Theng, G. Lagaly, Handbook of Clay Science, $1^{\text {st }}$ Ed., Elsevier Science, New York, EUA (2006).

[2] P.S. Santos, Ciência e Tecnologia de Argilas, $2^{\text {nd }}$ Ed., Edgard Blucher, S. Paulo (1989).

[3] A.G. Cairns-Smith, Theo. Biol. 10 (1965) 53.

[4] G.P. Souza, R. Sanchez, J.N.F. de Holanda, Ceramica 48, 306 (2002) 102.

[5] L. Paiva, A.R. Morales, F.R. Valenzuela-Diaz, Cerâmica 54, 330 (2008) 213.

[6] R.R. Menezes, L.R.L. Melo, F.A. S. Fonseca, H.S. Ferreira, A.B. Martins, G.A. Neves, Revista Eletrônica Materiais Processos 3 (2008) 36.

[7] M.J. Coelho, M. Cabral-Junior, II Simpósio de Minerais Industriais do Nordeste, Campina Grande, PB (2010) 9.

[8] A.E. Zanini, "Purificação e Organolização de Argilas Bentonitas para uso em Nanocompósitos Poliméricos", Diss. Mestrado, Universidade Federal de Campina Grande, Campina Grande, PB (2008).

[9] T.H.C. Silva, Sumário Mineral (2011), Disponível em: www.dnpm.gov.br.

[10] L.A. Utracki, Clay-Containing Polymeric
Nanocomposites, $1^{\text {st }}$ Ed., Rapra Technology Limited (2004). [11] G.G. Stokes, Trans. Cambridge Philosophical Soc. 9 (1851) 8 .

[12] A.E. Zanini, M.E. de Souza, M.L.F. Nascimento, L.H. de Carvalho, "Processo de Seleção, Purificação e Modificação Físico-Química de Sistemas Particulados Via Elutriação Matricial Iterativa e Produtos Aperfeiçoados", INPI - Instituto Nacional da Propriedade Industrial, Patente: Privilégio de Inovação. Número do registro: BR1020130162981, Brasil (2013).

[13] H.M. Rietveld, Acta Crystallographica 22 (1967) 151.

[14] H.M. Rietveld, J. Appl. Crystallography 2 (1969) 65.

[15] F. Schulze, U.S. Ackererde, J. für Praktische Chemie 16 (1839) 504.

[16] H.G. Schurecht, J. Am. Ceram. Soc. 3, 5 (1920) 355.

[17] H.G. Schurecht, J. Am. Ceram. Soc. 4, 10 (1921) 812.

[18] R.B. Bird, W.E. Stewart, E.N. Lightfoot, Fenômenos de Transporte, $2^{\text {nd }}$ Ed., LTC Editora (2004).

[19] W. Keller, K. Matlack, Appl. Clay Sci. 5, 2 (1990) 123.

[20] L. Bleicher, J. M. Sasaki, C.O.P. Santos, J. Appl. Crystallography 33 (2000) 1189.

[21] A. Viani, A.F. Gualtieri, G. Artioli, Am. Mineralogist 87 (2002) 966.

[22] D.L. Bish, R.B. Von Dreele, Clays Clay Minerals 37 (1989) 289.

[23] A. Manceau, D. Chateigner, W.P. Gates, Phys. Chem. Minerals 25 (1998) 347.

[24] A.F. Gualtieri, J. Appl. Crystallography 33 (2000) 267. [25] L.A. Utracki, B. Broughton, N. Gonzalez-Rojano, L.H. Carvalho, C.A. Achete, Polymer Eng. Sci. 51 (2011) 559.

(Rec. 09/06/2015, Ac. 24/08/2015) 